\title{
Effect of cimetidine on augmented gastric blood flow in duodenal ulcer patients
}

\author{
L IVARSSON, N DARLE, AND O LUNDGREN \\ From the Department of Surgery at Östra Sjukhuset and Department of Physiology, University of Göteborg, \\ Sweden
}

SUMMARY Blood flow in the human stomach was measured during operation with a ${ }^{85}$ Krypton washout method which made simultaneous determinations of total blood flow and intramural flow distribution possible. The antrum and the corpus of the stomach could be investigated separately. Eleven patients with duodenal ulcer disease were studied during pentagastrin infusion and after the addition of cimetidine, $3 \mathrm{mg} / \mathrm{kg}$ bw, to evaluate the effect of the drug on augmented gastric blood flow. Eight recordings were made over the corpus of the stomach and three recordings over the antrum. Cimetidine caused a $66 \pm 5 \%$ decrease (mean $\pm S E$; range 56-86) in acid secretion and a $62 \pm 5 \%$ decrease (range 44-91) in the corpus mucosal blood flow within 15 minutes. Changes were only seen in the acid secreting part of the stomach while the antral circulation remained unaltered. It is concluded that the decrease in pentagastrin induced vasodilatation in the stomach seen after giving cimetidine was secondary to an inhibition of acid secretion.

The pathophysiology of the duodenal ulcer disease is still a matter of research and considerable efforts are devoted to finding new methods for prevention and treatment. The introduction of the histamine $\mathrm{H}_{2}$-receptor antagonists initiated new investigations, not only in the treatment of the uncomplicated ulcer but the drugs were soon tested in the treatment of a serious complication of ulcer disease, acute bleeding. The results of these studies are in some respects contradictory but a pattern is emerging on which a rationale for treatment may be founded. It appears that the bleeding from an established peptic ulcer, especially if it is located in the distal stomach or the duodenum, is largely unresponsive to histamine $\mathrm{H}_{2}$-receptor antagonism, ${ }^{1-3}$ while gastric ulcers and diffuse bleeding disorders in the gastric mucosa respond more favourably to this treatment. $^{3-5}$

The importance of an altered gastric blood flow in the pathogenesis and treatment of the ulcer disease is not clear. Available information on the effect of histamine $\mathrm{H}_{2}$-receptor antagonism on augmented gastric mucosal blood flow suggest a marked decrease. ${ }^{7} \mathrm{~A}$ limitation of the studies reported, where a marker clearance method (neutral red) was Address for correspondence: Ove Lundgren, Department of Physiology,
University of Göteborg, PO Box 33031, S-400 33 Göteborg. Sweden

Received for publication 5 December 1983 used, is that this method only reflects blood flow to the secreting part of the gastric mucosa, possibly only to the parietal cell mass, while the majority of peptic ulcer bleedings originate elsewhere in the stomach or duodenum.

Using an inert gas washout method, which provides information on total gastric blood flow as well as on its intramural distribution, we have earlier studied in a quantitative manner the gastric blood flow in normal subjects and duodenal ulcer patients. These studies showed that duodenal ulcer patients exhibited a different pattern of gastric blood flow from normal subjects, both in size and distribution. ${ }^{89}$ In the present study we investigated the effect of cimetidine on blood flow in the actively secreting human stomach. These studies were performed intraoperatively in duodenal ulcer patients. A few studies were also carried out in a series of experiments on the cat and these are also reported below.

\section{Methods}

The methods used in this study have been applied in human studies earlier for the determination of gastric small intestinal and colonic blood flow. They are described in detail previously. ${ }^{8-11}$ The theoretical framework of the inert gas elimination 
methods has been outlined and discussed in detail by Kety, ${ }^{12}{ }^{13}$ Zierler, ${ }^{14}$ and Bassingthwaighte. ${ }^{15} 16$

\section{CAT EXPERIMENTS}

The animal studies were performed on five cats anaesthetised with chloralose $(50 \mathrm{mg} / \mathrm{kg} \mathrm{bw})$ after induction with ether. The cats breathed spontaneously via a tracheostomy. The gastric preparation for recording venous outflow (total gastric blood flow) was the same as described previously. ${ }^{8}$

${ }^{85} \mathrm{Kr}$, dissolved in physiological saline, was injected into the coeliac artery via a catheter in the central end of the divided hepatic artery. Radioactivity was measured with a thalliumactivated NaI-crystal placed $3-5 \mathrm{~cm}$ from the surface of the stomach. The scintillation detector was coupled to a spectrometer and a linear ratemeter. Pulse corresponding to $\gamma$-energies above $70 \mathrm{keV}$ were counted. Atropine was not administered. Cimetidine, 3-4 $\mathrm{mg} / \mathrm{kg}$ bw was given as bolus injections intravenously.

\section{HUMAN STUDIES}

Measurements of gastric blood flow were carried out in 11 patients during surgery for duodenal ulcer disease. In three patients recordings were done over the antrum and in eight patients over the corpus of the stomach.

Droperidol-fentanyl, nitrous oxide, and oxygen were used for anaesthesia. Atropine was not included in the premedication of the patients. Respiration was controlled with an Engström respirator adjusted to maintain arterial $\mathrm{pCO}_{2}$ within normal limits. Expired air and radioactive gases were evacuated via a safety system to avoid recirculation or accumulation in the operating room.

The study was approved by the Ethical and Isotope Committees at the University of Göteborg. The patients were informed about the purpose and purely scientific aim of the study and gave consent to participation.

\section{Intra-arterial injection of ${ }^{85} \mathrm{Kr}$}

In all cases the stomach was prepared and the recording apparatus applied as described earlier. ${ }^{8}$ The radioactive isotope $\left(1 \mathrm{mCi}{ }^{85} \mathrm{Kr}\right.$ in one $\mathrm{ml}$ saline) was injected via a catheter (Portex, OD 1.02 $\mathrm{mm}$ ) placed in the gastroepiploic artery. The arterial catheter was directed either towards the antrum or towards the corpus, to enable flow recordings in these two regions separately. The disappearence of the isotope, which emits both $\beta$ - and $\gamma$-radiation, was monitored with a scintillation detector and a G-M tube. ${ }^{8}$

\section{Determination of acid secretion}

Acid secretion was determined preoperatively in all patients. In four patients routine studies were done, with determination of basal and peak acid output, using pentagastrin (Peptavlon ${ }^{R}$, kindly supplied by ICI), six $\mu \mathrm{g} / \mathrm{kg}$ bw given subcutaneously as a secretory stimulant. In the remaining seven patients a modified secretion study was done. In this study, basal acid butput was determined as usual. Peak acid output was determined during one hour of continuous pentagastrin infusion, $600 \mathrm{ng} / \mathrm{kg} \times \mathrm{h}$. Cimetidine was then given as an intravenous bolus, $3 \mathrm{mg} / \mathrm{kg}$ bw, while the pentagastrin infusion was maintained. The effect of cimetidine on stimulated acid secretion was followed during three consecutive 15 minute periods.

\section{STATISTICS}

Blood flow (F) in the muscle layer tissue, as reflected by the disappearance of $\beta$-radiation, was calculated using Kety's equation ${ }^{12}{ }^{3}$ for blood flow determination in homogenously perfused tissues:

$$
\mathrm{F}=\frac{\ln 2}{\mathrm{t} \frac{1}{2}} \times \lambda \times 100
$$

$\lambda$, the tissue-blood partition coefficient was set to 0.84 for ${ }^{85} \mathrm{Kr} .{ }^{89}$ The washout curve was plotted semilogarithmically and blood flow calculated from the straight line obtained. The straightness of the line obtained after plotting served as a control of the experimental conditions, any change in its slope indicating an altered perfusion during the recording.

Total gastric blood flow was calculated from the linear plot of the $\lambda$-elimination curves, using the equation proposed by Zierler $^{14}$ as modified by Bassingthwaighte. ${ }^{15} 16$

$$
\mathrm{F}=\frac{\mathrm{C}_{\mathrm{P}}-\mathrm{C}_{\mathrm{T}}}{\int_{0}^{\mathrm{T}} \mathrm{C}(\mathrm{t}) \mathrm{dt}} \times \lambda \times 100
$$

where $C_{p}=$ peak value of recorded radioactivity; $C_{T}$ $=$ radioactivity at time $T$.

The relative weights of the wall layers of the stomach were determined in resected gastric specimens, from duodenal ulcer patients in the following manner: after fixation in formalin and staining with haematoxylin-eosin, slices $2 \mu \mathrm{m}$ thick were cut from the stomach wall. Specimens were photographed with a macro-lens (magnification, $\times 5$ ). The muscle and mucosa-submucosa layers, cut from the photographic paper were weighed (accuracy $1 / 1000 \mathrm{~g}$ ) and the relative weights calculated. In 10 specimens from the antrum the relative muscle and mucosa-submucosa weights were $48 \pm 3 \%$ and $52 \pm 3 \%$ ( $\overline{\mathrm{x}} \pm \mathrm{SD})$. In 11 corpus specimens the corresponding weights were $39 \pm 4 \%$ and $61 \pm 4 \%$. 
Knowing these weight ratios, mean blood flow in the mucosa-submucosa could be calculated from the measurements of total gastric blood flow $(\gamma$ recording) and muscle layer blood flow ( $\beta$ recording).

\section{Results}

\section{CAT STUDIES}

The cat experiments were primarily performed to establish at which time, $T$, the recording of the elimination should be terminated. This question was studied in five animals (eight runs). Pentagastrin was infused throughout the experiments in doses ranging from 500 to $800 \mathrm{ng} / \mathrm{kg} \times \mathrm{h}$. Blood flow recordings, using the ${ }^{85} \mathrm{Kr}$ washout and venous outflow techniques simultaneously, were done before and after the cat had been given cimetidine $3-4 \mathrm{mg} / \mathrm{kg}$ bw, as a bolus dose intravenously. Recordings of the elimination of ${ }^{85} \mathrm{Kr}$ were started 5-10 minutes after cimetidine had been given. Upon drug injection total gastric blood flow decreased moderately, at most about $30 \%$. In order to reproduce the experimental situation in the human studies, no effort was made to await maximal effect of the injected drug (see Discussion). The curves, recorded by the scinitillation detector, were plotted on a linear diagram and the flow calculated according to Bassingthwaighte's modification of Zierler's original formula (equation 2). Blood flow was estimated from washout curves where the tail of the curves had been excluded at different times, $T$. The tracer concentration at $T, C_{T}$, was related to the peak radioactivity recorded, $C_{P}$, during each washout period. The ratio $C_{T}: C_{P}$ was varied between 0.20 and 0.60 as illustrated in Fig. 1 and the relationship between the estimated and measured flow was determined at each $\mathrm{C}_{\mathrm{T}}: \mathrm{C}_{\mathrm{P}}$ value. Figure 1 shows that a good agreement between the two methods was observed at a $C_{T}: C_{P}$ ratio around 0.5 before and 0.4 after giving cimetidine. These values were therefore used for calculating corpus blood flow before and after giving the drug. The 'resting' ratio of 0.20 was used when calculating blood flow in the antrum, under the same experimental conditions. ${ }^{89} 17$

\section{HUMAN STUDIES}

Validation of the method

It was shown in an earlier study that human gastric blood flow was markedly increased during maximal gastric acid secretion evoked by pentagastrin..$^{15}$ The vasodilatation was confined to the mucosalsubmucosal layer to which about $95 \%$ of total gastric blood flow was distributed. ${ }^{15}$ Consequently, a monoexponential washout, probably reflecting

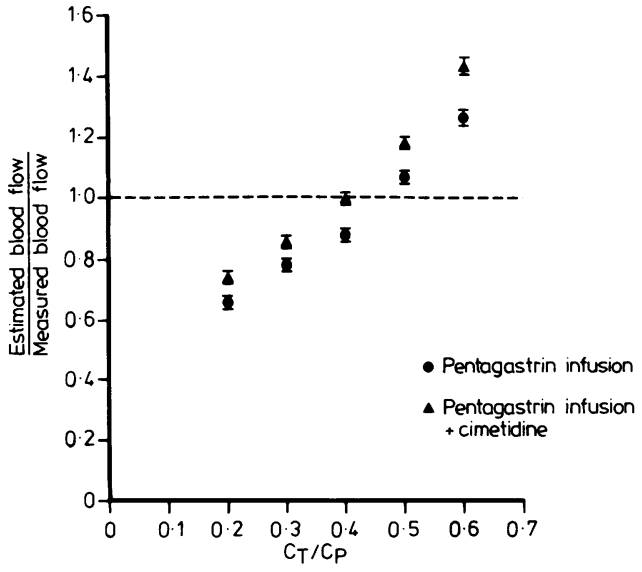

Fig 1 Ratio between estimated gastric blood flow in cat (determined from ${ }^{85} \mathrm{Kr}$ washout curves) and measured gastric blood flow (determined from recordings of total venous outflow) correlated to $C_{T}: C_{P}$ ratio during pentagastrin infusion before and after cimetidine. Bars denote $S E$.

blood flow in the mucosa, was observed in the initial part of the elimination curve recorded by the scintillation detector, as the small portion of radioactivity distributed to the muscle layer did not appreciably influence the initial shape of the curve. A comparison was therefore made between blood flow estimated from the initial slope (calculated according to Kety; equation 1) and the average blood flow estimated in the mucosa-submucosa (calculated according to Bassingthwaighte et al as described in Methods). Figure 2 gives the results, when performing such an analysis on flow studies where total gastric blood flow exceeded $100 \mathrm{ml} / \mathrm{min}$ $\times 100 \mathrm{~g}$ in which muscle layer blood flow was $5 \%$ of total flow or less in all studied subjects except one. Observations made in this and previous studies ${ }^{9}$ were included in this Figure, showing a fairly good correlation between the two methods $(r=0 \cdot 76)$. As expected, average blood flow in the mucosasubmucosa was lower than that calculated from the initial slope, the latter reflecting mainly blood flow in the secretory portions of the mucosa.

\section{Blood flow and flow distribution}

A continuous infusion of pentagastrin, $600 \mathrm{ng} / \mathrm{kg} \times$ $h$, was started in all patients once anaesthesia was induced. The first recording of pentagastrin stimulated blood flow, was performed 30-35 minutes later, immediately after which cimetidine was given as a bolus intravenously $(3 \mathrm{mg} / \mathrm{kg} \mathrm{bw})$. The operative situation did not make it feasible to await maximal effect of the $\mathrm{H}_{2}$-receptor blockade 


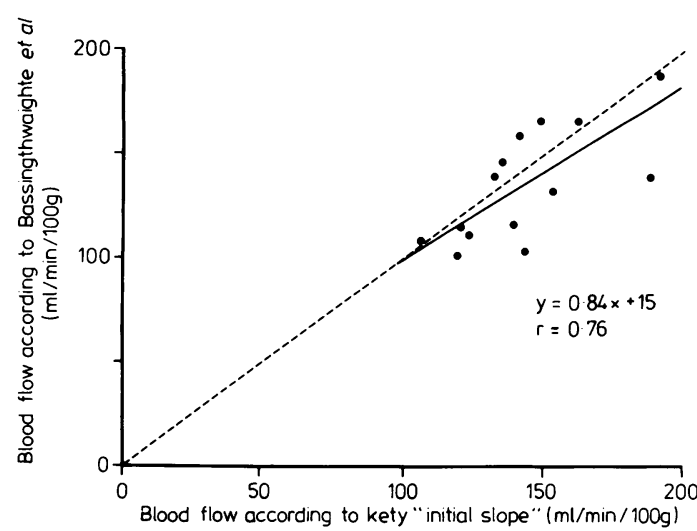

Fig 2 Correlation between mucosal-submucosal blood flow values estimated according to Bassingthwaighte and from initial slope according to Kety. Line was constructed according to method of least squares. Dotted line indicates line of identity.

and the second injection of ${ }^{85} \mathrm{Kr}$ was therefore carried out five minutes after cimetidine was given. Each recording took 5-10 minutes. In three cases recordings were made over the antrum and in eight cases over the corpus of the stomach. The calculated values for total blood flow and flow distribution before and after cimetidine are given in the Table. There was a significant decrease in total gastric blood flow and in blood flow to mucosa-submucosa layer tissue in all patients where the secretory part of the stomach was studied $(\mathrm{p}<0.05$; Wilcoxon's rank sum test). In the muscle layer tissue no significant changes were found. The results indicate that the decrease of corpus blood flow seen after cimetidine reflects a decrease of blood flow occurring only in the mucosa-submucosa. The flow determinations in the antrum revealed no changes, although the number of observations are too few to allow statistical analysis.

\section{Blood flow and acid secretion}

Gastric acid secretion was determined preoperatively in seven patients, before and after giving cimetidine as described in Methods. Cimetidine decreased the pentagastrin induced secretion in all subjects studied. Within 15 minutes the peak acid secretion was reduced to $34 \pm 5 \%$ (Mean $\pm \mathrm{SE}$ ) of that observed after pentagastrin. Between 30 and 45 minutes after the cimetidine bolus was given, the secretion rate had decreased further, to $19 \pm 4 \%$ of maximum. Blood flow in the corpus mucosasubmucosa tissue layer, recorded five minutes after injection of cimetidine decreased as illustrated in Fig. 3, where flow is plotted versus acid secretion.

The response was remarkably similar in most studied subjects, even from a quantitative point of view. Figure 3 also shows that there was no apparent relationship in the antrum between blood flow in the mucosa-submucosa tissue layer and acid secretory capacity.

Table Blood flow and flow distribution in the actively secreting human stomach, before and after cimetidine

\begin{tabular}{|c|c|c|c|c|c|c|c|c|c|c|}
\hline \multirow[b]{3}{*}{$\begin{array}{l}\text { Patient } \\
\text { (no) }\end{array}$} & \multicolumn{5}{|c|}{ Pentagastrin infusion, $600 \mathrm{ng} / \mathrm{kg} \times h$} & \multicolumn{5}{|c|}{ Pentagastrin infusion, $600 \mathrm{ng} / \mathrm{kg} \times \mathrm{h}$ and cimetidine $3 \mathrm{mg} / \mathrm{kg}$} \\
\hline & \multicolumn{3}{|c|}{ Blood flow, $\mathrm{ml} / \mathrm{min} \times 100 \mathrm{~g}$} & \multicolumn{2}{|c|}{ Flow distribution $\%$} & \multicolumn{3}{|c|}{ Blood flow, $\mathrm{ml} / \mathrm{min} \times 100 \mathrm{~g}$} & \multicolumn{2}{|c|}{ Flow distribution $\%$} \\
\hline & Total & $\begin{array}{l}\text { Mucosa- } \\
\text { submucosa }\end{array}$ & $\begin{array}{l}\text { Muscle- } \\
\text { layer }\end{array}$ & $\begin{array}{l}\text { Mucosa- } \\
\text { submucosa }\end{array}$ & $\begin{array}{l}\text { Muscle- } \\
\text { layer }\end{array}$ & Total & $\begin{array}{l}\text { Mucosa- } \\
\text { submucosa }\end{array}$ & $\begin{array}{l}\text { Muscle- } \\
\text { layer }\end{array}$ & $\begin{array}{l}\text { Mucosa- } \\
\text { submucosa }\end{array}$ & $\begin{array}{l}\text { Muscle- } \\
\text { layer }\end{array}$ \\
\hline \multicolumn{11}{|l|}{ Corpus } \\
\hline 1 & 95 & 149 & 12 & 95 & 5 & 41 & 57 & 16 & 85 & 15 \\
\hline 2 & 139 & 222 & 10 & 97 & 3 & 76 & 118 & 9 & 95 & 5 \\
\hline 3 & 77 & 119 & 10 & 95 & 5 & 29 & 41 & 10 & 87 & 13 \\
\hline 4 & 66 & 104 & 7 & 96 & 4 & 34 & 51 & 8 & 91 & 9 \\
\hline 5 & 48 & 75 & 4 & 96 & 4 & 21 & 31 & 6 & 89 & 11 \\
\hline 6 & 106 & 162 & 18 & 93 & 7 & 33 & 45 & 14 & 83 & 17 \\
\hline 7 & 88 & 135 & 7 & 97 & 3 & 11 & 12 & 9 & 68 & 32 \\
\hline 8 & 98 & 153 & 6 & 98 & 2 & 54 & 85 & 5 & 96 & 4 \\
\hline Mean & 90 & 140 & 9 & 96 & 4 & 37 & 55 & 10 & 87 & 13 \\
\hline SE & 10 & 15 & 2 & 0.5 & 0.5 & 7 & 12 & 1 & 3 & 3 \\
\hline \multicolumn{11}{|c|}{ Antrum } \\
\hline 9 & 27 & 41 & 11 & 80 & 20 & 30 & 48 & 9 & 85 & 15 \\
\hline 10 & 21 & 37 & 4 & 91 & 9 & 16 & 27 & 4 & 88 & 12 \\
\hline 11 & 20 & 34 & 4 & 90 & 10 & 20 & 34 & 5 & 88 & 12 \\
\hline Mean & $24 \cdot 5$ & 37 & 6 & 87 & 12 & 22 & 36 & 6 & 87 & 13 \\
\hline SE & 2 & 2 & $2 \cdot 5$ & $3 \cdot 5$ & $3 \cdot 5$ & 4 & 6 & 2 & 1 & 1 \\
\hline
\end{tabular}

Blood flow is expressed per $100 \mathrm{~g}$ of the respective tissue. 


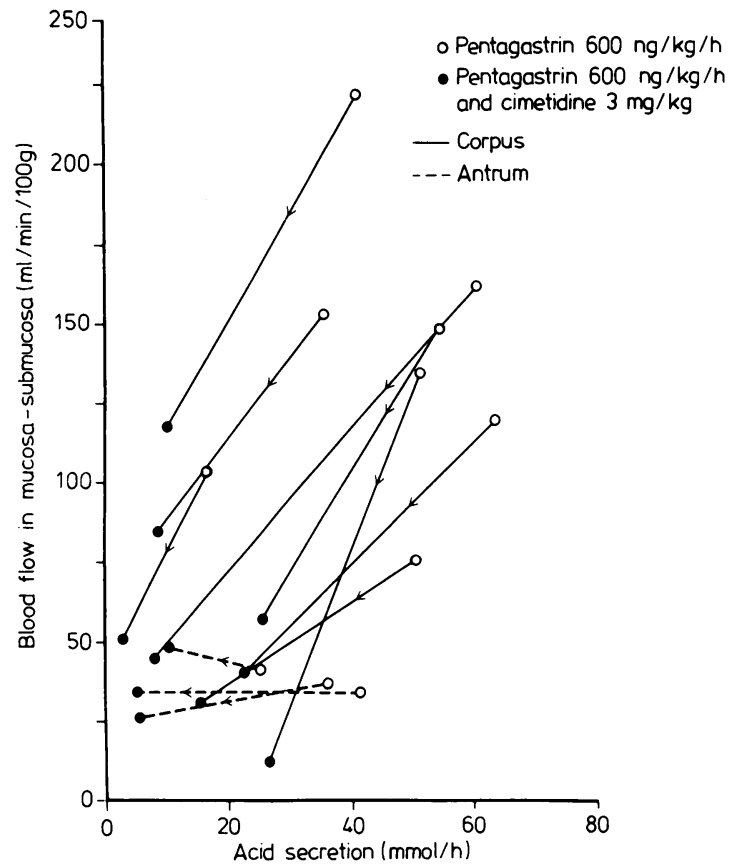

Fig 3 Mucosa-submucosa blood flow in the corpus and antrum in 11 duodenal ulcer patients during pentagastrin infusion, before and after the addition of cimetidine. Blood flow is correlated to peak acid output and acid output 15 minutes after cimetidine determined preoperatively.

\section{Discussion}

The importance of gastric blood flow for ulcer formation and bleeding disorders in the stomach duodenum is not clear. The effects on blood flow of various anti-ulcer drugs are insufficiently known, mainly for lack of a suitable measuring method, applicable in man. The methods available are mostly based on marker clearance ${ }^{18-20}$ and, consequently, measure only blood flow in the secretory part of the gastric mucosa. Also, their validity in quantifying that particular flow is being questioned, especially for determination of resting blood flow. ${ }^{21}{ }^{22}$ The qualitative analysis they allow, however, is in accordance with results obtained in animal experiments, using other techniques. ${ }^{23} 24$

An established concept is that an increase in acid secretion cannot occur without an increase in mucosal blood flow and that reduced acid secretion results in a decrease in flow under physiological conditions. ${ }^{25}$ This has also been shown to be true for the human stomach using the present and other techniques. ${ }^{7-9} 1826$ In consequence, drugs which reduce acid secretion have been tried in the treatment of upper gastrointestinal bleedings. ${ }^{1-}$ 52728 Early clinical reports and experimental evidence indicated that the histamine $\mathrm{H}_{2}$-receptor antagonists cimetidine effectively reduced gastric mucosal blood flow and increased intragastric $\mathrm{pH}^{26}{ }^{29} 30$ albeit only in situations with active secretion and augmented flow. ${ }^{31}$ In a number of ensuing clinical reports on the effect of cimetidine in patients with gastroduodenal bleedings the results have been less impressive, both when the drug was used for treatment and for prophylaxis, ${ }^{1326}$ making the whole issue unsettled.

To investigate what effect cimetidine might have on the size and distribution of augmented gastric blood flow we studied 11 duodenal ulcer patients intraoperatively. Application of a recently developed inert gas washout method, based on the $\beta$ - and $\gamma$-emitting properties of the isotope ${ }^{85} \mathrm{Kr}$, enabled simultaneous determination of total blood flow and blood flow distribution to the wall layers of the stomach. The method has earlier been applied to the study of colonic and small intestinal blood flow in $\operatorname{man}^{10} 11$ and the present modification allows measurement also of gastric blood flow in man. ${ }^{89}$ In animal studies and in human intestinal blood flow recordings the blood flow recordings can be validated with independent, simultaneously used techniques, for instance recording of venous outflow or isotope elimination after local injections in the various tissue layers studied. ${ }^{10}{ }^{11}$ The local isotope injection technique was used also in the human stomach in an earlier study and a fairly good comparison could be shown between the flow values for gastric mucosa estimated from the elimination curves recorded after intra-arterial and local tissue injections. ${ }^{9}$ Moreover, the corresponding mucosal blood flow values found when using two different methods for the calculations serve to validate the method and the $C_{T}: C_{P}$ ratio used (see Fig. 2).

The operative situation necessitated that the effect of cimetidine had to be measured starting five minutes after the drug was given - that is, before its full effect on acid secretion was reached. This probably implies that the effect of cimetidine on gastric blood flow was, if anything, underestimated.

Cimetidine evoked similar qualitative and quantitive changes in acid secretion and blood flow in all subjects studied (Table). We found that the induced change entirely reflected a decreased mucosa-submucosa blood flow in the corpus part of the stomach (Fig. 3), suggesting that observed flow effects of cimetidine reflected a change of the local chemical environment secondary to the decreased acid secretion.

In the muscle layer tissue of the corpus and in the whole of the antral wall virtually no change was seen nor did the blood flow in these parts of the stomach respond much to pentagastrin. ${ }^{9}$ This sheds some 
doubt on the importance of histamine $\mathrm{H}_{2}$-receptors in the direct regulation of gastric microcirculation. ${ }^{63233}$ Also, it provides a possible explanation as to why cimetidine fails to influence bleeding from the antral area, the source of bleeding here usually being from a peptic ulcer.

We have earlier studied the effect of pentagastrin on gastric blood flow in duodenal ulcer patients. In the corpus mucosa a 12-fold increase was found, compared with a five to six fold increase in the normal subjects. Our results from the present study indicate that half of this increase was abolished within 15 minutes after the injection of a therapeutic dose of cimetidine. We did not see any change in the relation between acid secretion and blood flow when either of these decreased in accordance with earlier observations. ${ }^{9}$ We therefore assume that the same dose of cimetidine is sufficient to bring blood flow down to a normal 'resting' level for duodenal ulcer patients, in accordance with results from the neutral red clearance studies. ${ }^{7}$

It has not yet been possible to study the blood flow in the duodenum with the ${ }^{85} \mathrm{Kr}$-washout method. Considering the absence of parietal cells in the duodenal mucosa and the common arterial supply to the duodenum and the antrum it seems unlikely that cimetidine should have a different effect on the blood flow in the duodenum than on the antral circulation.

Thus, when using anti-secretory agents in attempts to control gastroduodenal bleeding the difference in effects on secretory and non-secretory parts of the mucosa must be considered. Cimetidine appears to have a profound influence on blood flow in the secretory gastric mucosa but the question if and when this effect is desirable in the clinical situation is not yet answered. Our findings support the observations that the drug may be effective in the temporary control of diffuse bleeding disorders from the corpus of the stomach. Recent experimental evidence indicates, however, that the prolonged use of cimetidine in this situation may indeed be harmful to the integrity of the gastric mucosa. ${ }^{34}$

This study was supported by grants from the Medical Society of Göteborg, the University of Göteborg and the Swedish Medical Research Council (no 2855). Isotope solution was generously supplied by Smith, Kline \& French Research Ltd, England.

\section{References}

1 Carstensen HE, Bülow S, Hart Hansen $\mathrm{O}$ et al. Cimetidine for severe gastroduodenal haemorrhage: a randomized controlled trial. Scand $J$ Gastroenterol 1980; 15: 103-5.

2 Hoare AM, Bradby GVH, Hawkins CF, Kang JY, Dykes PW. Cimetidine in bleeding peptic ulcer. Lancet 1979; 2: 671-3.

3 LaBrooy SJ, Misiewicz JJ, Edwards J et al. Controlled trial of cimetidine in upper gastrointestinal haemorrhage. Gut 1979; 20: 892-5.

4 Dykes PW, Hoare AM, Hawkins CF, Kang JY. The treatment of upper gastrointestinal haemorrhage with cimetidine. In: Wastell C, Lance P, eds. Cimetidine. The Westminster Hospital Symposium Edinburgh. Churchill-Livingstone, 1978: 173-9.

5 MacDonald AS, Steele BJ, Bottomley MG. Treatment of stress-induced upper gastrointestinal haemorrhage with metiamide. Lancet 1976; 1: 68-70.

6 Knight SE, McIsaac RL, Fielding LP. Effect of the histamine $\mathrm{H}_{2}$-receptor antagonist cimetidine on gastric mucosal blood flow. [Abstract] Gut 1977; 18: A948.

7 Knight SE. Gastric acid secretion and gastric mucosal blood flow. In: Truelove SC, Willoughby CD, eds. Topics in gastroenterology 7. Oxford: Blackwell, 1979; 69-83.

8 Ivarsson LE, Darle $\mathrm{N}$, Hultén L, Lindhagen J, Lundgren $\mathrm{O}$. Gastric blood flow and distribution in cat and man as studied by an inert gas elimination method. Scand J Gastroenterol 1982; 17: 1025-30.

9 Ivarsson LE, Darle $\mathrm{N}$, Hultén L, Lindhagen $\mathrm{J}$, Lundgren $\mathrm{O}$. Gastric blood flow and distribution: the effect of pentagastrin in cat and man as studied by an inert gas elimination method. Scand J Gastroenterol 1982; 17: 1037-48.

10 Hultén L, Jodal M, Lindhagen J, Lundgren O. Colonic blood flow in cat and man as analysed by an inert gas washout technique. Gastroenterology 1976; 70: 35-44.

11 Hultén L, Jodal M, Lindhagen J, Lundgren O. Blood flow in the small intestine of cat and man as analysed by an inert gas washout technique. Gastroenterology 1976; 70: $45-51$.

12 Kety SS. Theory and application of the exchange of inert gases at the lungs and tissues. Pharmacol Rev 1951; 3: 1-14.

13 Kety SS. Theory of blood-tissue exchange and its application to measurement of blood flow. Methods Med Res 1960; 8: 223-7.

14 Zierler KH. Equations for measuring blood flow by external monitoring of radioisotopes. Circ Res 1965; 16: 309-21.

15 Bassingthwaighte JB, Strandell T, Donald DE. Estimation of coronary blood flow by washout of diffusible indicators. Circ Res 1968; 23: 259-78.

16 Bassingthwaighte JB. Blood flow and diffusion through mammalian organs. Science 1970; 167: 1347-53.

17 Lundgren $O$. Use of inert gas washout for studying blood flow and flow distribution in the intestine. In: Granger DN, Bulkley GB, eds. Measurement of blood flow; applications to the splanchic circulation. Baltimore: William \& Wilkins, 1981: 225-43.

18 Guth P, Baumann H, Grossman MI, Aures D, Elashoff $\mathrm{J}$. Measurement of gastric mucosal blood flow in man. Gastroenterology 1978; 74: 831-4.

19 Knight SE, McIsaac RL. Neutral red clearance as an 
estimate of gastric mucosal blood flow in man. $J$ Physiol 1977; 272: 62P.

20 Taylor TV, Pullan BR, Elder JB, Torrance B. Observations of gastric mucosal blood flow using Tc in rat and man. Br J Surg 1975; 62: 788-91.

21 Archibald LH, Moody FG, Simon MA. Comparisons of gastric mucosal blood flow as determined by aminopyrine clearance and gamma-labelled microspheres. Gastroenterology 1975; 69: 630-5.

22 Sonnenberg A, Blum AL. Limitations to measurement of gastric mucosal blood flow by $\mathrm{C}$-aminopyrine clearance. In: Fielding LP, ed. Gastro-intestinal mucosal blood flow. Edinburgh: Churchill-Livingstone, 1980: 43-58.

23 Archibald LH, Moody FG, Simon MA. The measurement of gastric mucosal blood flow by radioactive microspheres. J Appl Physiol 1975; 36: 1051-6.

24 Delaney JP, Grim E. Canine gastric blood flow and its distribution. Am J Physiol 1964; 207: 1195-202.

25 Jacobson ED, Swan KG, Grossman MI. Blood flow and secretion in the stomach. Gastroenterology 1967; 52: 414-20.

26 Murakami $M$, Moriga $M$, Miyake $T$, Uchino $H$. Contact electrode method in hydrogen gas clearance technique: a new method for determination of regional gastric mucosal blood flow in animals and humans.
Gastroenterology 1982; 82: 457-67.

27 Picard RG, Sandersson I, South M, Kirkham JS, Northfield TC. Controlled trial of cimetidine in acute upper gastrointestinal bleeding. $\mathrm{Br} \mathrm{Med} J$ 1979; 1: 661-2.

28 Rimsten $\AA$, Wiklund L, Krause U. Propantheline bromide in massive upper gastro-intestinal haemorrhage. Upsala J Med Sci 1975; 80: 34-40.

29 Cheung LY, Lowry SF. Canine gastric blood flow and oxygen consumption during cimetidine inhibition of gastric secretion. Surg Forum 1976; 27 : 390-2.

30 Herrman V, Kaminski DL. Evaluation of intragastric $\mathrm{pH}$ in acutely ill patients. Arch Surg 1979; 114: 511-4.

31 Delaney JP, Michel HM, Bond J. Cimetidine and gastric blood flow. Surgery 1977; 84: 190-2.

32 Knight SE, McIsaac RL, Rennie CD. The effect of histamine and histamine antagonists on gastric acid secretion and mucosal blood flow in man. Br J Surg 1980; 67: 266-9.

33 Pawlik W, Tague LL, Tepperman ML, Miller TA, Jacobson ED. Histamine $\mathrm{H}_{1}$ - and $\mathrm{H}_{2}$-receptor vasodilatation of canine intestinal circulation. Am J Physiol 1977; 233: E219-24.

34 Cheung LY, Sonnenschein LA. Effect of cimetidine on canine gastric mucosal $\mathrm{pH}$ and blood flow. Am J Surg 1983; 145: 24-9. 